\title{
Broom snakeweed responses to drought: I. Photosynthesis, conductance, and water-use efficiency
}

\author{
CHANGGUI WAN, RONALD E. SOSEBEE, AND BOBBY L. MCMICHAEL
}

\begin{abstract}
Authors are postdoctoral research associate and professor, Department of Range and Wildlife Management, Texas Tech University, Lubbock 79409, and plant physiologist, USDA-ARS, Cropping Systems Research Laboratory, Lubbock, Texas. Contribution No. T-9-629 of the College of Agricultural Sciences, Texas Tech University. The senior author is visiting scientist of Gansu Grassland Ecological Research Institute, Lanzhous, China.
\end{abstract}

\begin{abstract}
The effects of water deficit on photosynthesis, transpiration, stomatal conductance, canopy development, and water-use efficiency of broom snakeweed (Gutierrezia sarothrae (Pursh) Britt and Rusby) were studied during the spring-summer growing season in pot-grown plants subjected to 5 soil water regimes. Stomatal conductance was proportionately more reduced by a mild water stress (soil water potential $=-0.2 \mathrm{MPa}$ ) than were canopy development and photosynthesis. However canopy development was most affected by moderate to severe soil water deficit $(<-1.1$ MPa), followed by photosynthesis; transpiration and leaf conductance were least affected. When subjected to severe water stress, broom snakeweed controlled its water loss mainly through reduced canopy development rather than stomatal closure. Photosynthesis was more limited by mesophyll conductance than by stomatal conductance. Water-use efficiency was not affected by mild water stress. As soil water deficit developed, water-use efficiency declined, which was a response to nonstomatal limitation to photosynthesis and less sensitive stomata to severe water deficit. Broom snakeweed maintained positive net photosynthesis at soil water potential as low as $-3.4 \mathrm{MPa}$ and leaf water potential of $\mathbf{- 8 . 1 9} \mathrm{MPa}$. Waterspending behavior (low water-use efficiency) and high degree of drought tolerance were the main physiological characteristics of broom snakeweed subjected to water stress.
\end{abstract}

Key Words: rangeland xerophytes, water relations, gas exchange, drought tolerance, canopy development

Broom snakeweed (Gutierrezia sarothrae (Pursh) Britt and Rusby) is a widespread suffrutescent shrub in large areas of the semiarid rangelands of the western U.S. and southern Canada. Its population fluctuates according to climatic conditions (Pieper and McDaniel 1989). However, when it reaches densities common to many soutbwestern rangelands, it seems no longer cyclical, but rather predominates year after year (Sosebee 1988). The growth habits of snakeweed preclude grasses from growing in the same community. If soil water is adequate in the fall and winter, snakeweed will remain evergreen and use much of the available soil water during the period when warm-season grasses are dormant. In the early spring when grasses start growing, snakeweed has a distinct competitive advantage over grasses because of its above- and below-ground biomass.

Growth habit alone cannot fully explain the predominance of

Research was funded by USDA-ARS and the Institute for Plant Stress Research of Texas Tech University (Project No. 6208-22230-001-01S). Authors wish to thank Dr. Ray Brown for assistance in determination of the water retention curve with thermocouple psychometry. Authors also thank 4 anonymous reviewers for their contribu-

tion to the revision of the initial manuscript.
Manuscript accepted 21 Dec. 1992. broom snakeweed in the natural plant community. For example, in summer drought when most grasses become quiescent, snakeweed remains green and turgid. This may indicate that broom snakeweed can make better use of available soil water under soil water deficit than the grasses. In the Great Basin, the shallow-rooted snakeweed had a lower plant water potential than the deep-rooted drought resistant shrub big sagebrush (Artemisia tridentata spp. tridentata Nutt.), yet its stomatal conductance and photosynthesis were much higher than that of big sagebrush (DePuit and Caldwell 1975).

Chemical control of snakeweed has been successful in recent years. The cost of control, however, can significantly reduce the profit margin of the ranching operation. Since snakeweed infestations are cyclical, the question often arises as to whether the rancher should control snakeweed by spraying or wait for the possibility of the plants dying anyway because of limited soil moisture. Since snakeweed populations are influenced by weather patterns, it is incumbent on the scientific community to provide input to the rancher on the conditions and the probabilities that snakeweed will continue to remain evergreen, die-back to the perennial stems, or die out completely. This information is crucial for planning management strategies or evaluating the economics of investing in a control program. This information should include understanding of responses of various physiological parameters of broom snakeweed to soil water deficit.

DeLucia and Heckathorn (1989) suggested that ability of big sagebrush to compete with other species rests on its profligate use of water (low WUE) and high degree of drought tolerance. We hypothesize that the above physiological traits also exist in broom snakeweed when subjected to water stress, which allows this species to become a successful competitor on semiarid rangelands. Specific objectives of this research were to evaluate the impact of soil water deficit on the basic physiological processes of photosynthesis, transpiration, leaf conductance, water-use efficiency and canopy development.

\section{Materials and Methods}

Six hundred broom snakeweed seedlings were transplanted into 19-1 plastic pots $(30 \mathrm{~cm}$ high and $29 \mathrm{~cm}$ in diameter) from a rangeland plant community in west Texas in the fall of 1990 and grown in an outdoor nursery on the Texas Tech University campus. The pots were filled with Amarillo fine sandy loam (fineloamy, mixed, thermic Aridic Paleustalfs), a typical soil on which broom snakeweed grows on the southern High Plains of Texas. The plants had become well established before the experiment began in April, 1991. The 600 plants were separated into 5 treatments of 120 plants each. Plant size was stratified across treatments 
so that each treatment had 24 similar-sized plants (about $10 \mathrm{~cm}$ high) when the study began. The $10-\mathrm{cm}$ high plants were placed on benches $10-\mathrm{cm}$ from each other. The initial soil water content was kept at field capacity $(-0.03 \mathrm{MPa})$. Treatment 1 was irrigated twice a week ( $420 \mathrm{~g}$ of water per day per plant) to replace transpirational water loss ( 300 to $\mathbf{4 0 0} \mathrm{g}$ per day per plant) and hence maintain soil moisture at field capacity. The plants in Treatments 2 through 4 received $50 \%, 25 \%$, and $12.5 \%$ of the irrigation quota of Treatment 1. The plants in Treatment 5 were irrigated in mid April, and were not further irrigated during the experiment except at the end of the vegetative stage in late June. Treatments 1 through 5 were denoted as well watered (WW), slightly stressed (SS), moderately stressed (MS), severely stressed (SVS), and extremely stressed (ES), respectively. Plants subjected to the different soil water regimes were covered with a temporary "rain-out" shelter to protect them from natural precipitation events during experimentation. Measurements of the various physiological parameters were begun approximately 14 days after the experiment had begun and the treatments established.

Soil water content was monitored every month using time domain reflectometry (TDR) equipment (Topp et al. 1980, 1982 Ledieu et al. 1986, Dalton and Poss 1990). Stainless steel rods 0.32 $\mathrm{cm}$ in diameter were cut into $26 \mathrm{~cm}$ lengths and inserted permanently in 5 pots per treatment as TDR probes. Pairs of the rods were inserted horizontally into the soil at a parallel distance of $5 \mathrm{~cm}$ at 3 depths $(10,18$, and $26 \mathrm{~cm})$ within each pot. Soil electromagnetic capacitance and reflectance patterns were measured with a Tektronix $1502 \mathrm{C}$ cable tester (Textronix, Beaverton, Ore.) connected to the soil probes. The cable tester readings of electromagnetic wave length were converted to a dielectric constant $(K)$, and soil volumetric water content $\left(\phi_{\mathrm{p}}, \mathrm{cm}^{3} \mathrm{~cm}^{-3}\right)$ was calculated from $\mathrm{K}$ using the following empirical equation:

$$
\emptyset_{\mathrm{p}}=-5.3 * 10^{-2}+2.92 * 10^{-2} * \mathrm{~K}-5.5 * 10^{-4} * \mathrm{~K}^{2}+4.3 * 10^{-6 *} \mathrm{~K}^{3} \text { (Topp et al. }
$$
1980)

Volumetric water content $\left(\phi_{\mathrm{p}}\right)$ obtained with the TDR technique was calibrated with water content $\left(Q_{v}\right)$ determined gravimetrically. The average volumetric water content $\left(\boldsymbol{Q}_{v}\right)$ along a pair of rods was used to regress against the corresponding $\phi_{\mathrm{p}}$, and the following equation was derived:

$$
Q_{v}=-0.0313+1.14^{*} Q_{\mathrm{p}}\left(\mathrm{p}<0.0001, \mathrm{r}^{2}=0.95, \mathrm{n}=27\right)
$$

The slope of the line was not significantly different from 1 and the intercept was not significantly different from 0 , suggesting a 1:1 relationship.

Soil water retention curve was developed from thermocouple psychrometry, allowing soil water potential to be predicted from soil water content. The equation for the water retention curve was:

$$
\log (W C)=1.0925-0.3272 * \log (W P)\left(r^{2}=0.89, n=18\right)
$$

Where, WC is gravimetric water content (\%) and WP is soil water potential $(10 * \mathrm{MPa})$.

Photosynthesis (A), stomatal conductance (g), transpiration rate (E), and leaf and air temperatures were measured with a LI-6200 portable photosynthesis system (Licor Inc., Lincoln, Nebr.). The uppermost foliated twigs were used in the measurements. The measurements were taken at 10:00 a.m. on sunny days on 3 plants in each of the 5 treatments 3 times a month from late April until mid August (11 sampling days). Air temperatures were $30 \pm 2^{\circ} \mathrm{C}$, and photon flux density was $>1,200 \mu \mathrm{mol} \mathrm{m}^{-2} \mathrm{~s}^{-1} \mathrm{PAR}$ during the time when measurements were taken. Water-use efficiency (WUE) was determined as WUE $=\mathrm{A} / \mathrm{E}\left(\mathrm{mmol} \mathrm{CO}_{2} / \mathrm{mol}\right.$ $\mathrm{H}_{2} \mathrm{O}$ ) (Larcher 1982). Intercellular $\mathrm{CO}_{2}$ concentration $\left(\mathrm{Ci}, \mu \mathrm{L} \mathrm{L}^{-1}\right.$ ) was calculated by the software for the LI- 6200 photosynthesis system. Mesophyll conductance to $\mathrm{CO}_{2}\left(\mathrm{~g}_{\mathrm{m}}\right)$ was calculated as $\mathrm{g}_{\mathrm{m}}=\mathrm{A} / \mathrm{Ci}\left(\mathrm{mmol} \mathrm{m}^{-2} \mathrm{~s}^{-1}\right)$ (Fites and Teskey 1988). Midday plant water potential was measured with a Scholander-type pressure bomb once every month using 3 replicates. The very low plant water potentials in the severely stressed and extremely stressed treatments often caused equipment failure, thus only the data collected in June were presented.

The total canopy area was assumed to be proportional to the leaf area of an individual twig (Comstock et al. 1988). Therefore, canopy development was estimated from twig development. Twig development was determined as leaf area on individual twigs during the vegetative stage. Five twigs were harvested from 5 different plants in each treatment on each sampling date at time interval of 10 days. The leaf area was determined with a LI-3100 area meter (Licor inc., Lincoln, Nebr.). At the end of the vegetative stage (30 June), total canopy area (1 side) was measured.

The experimental design was completely randomized. Since measurements of photosynthesis, transpiration, and leaf conductance were made on the same individual plants of each treatment over the sampling dates, the results were analyzed by repeated measures analysis of variance (ANOVA). The treatment means were separated with Fisher's least significant difference at $\mathbf{p}<0.05$.

\section{Results and Discussion}

Soil water potential declined from $-0.023 \mathrm{MPa}$ in the wellwatered treatment to $-3.4 \mathrm{MPa}$ in the extremely stressed treatment, while the midday plant water potential declined from -2.85 to $-8.19 \mathrm{MPa}$ (Table 1). Plant water potential and relative water content both declined in response to soil drying.

As soil water decreased, average stomatal conductance and transpiration rate declined linearly (Fig. 1a, 1b). Plants in the well-watered treatment had the highest conductance and transpiration, followed in order by slightly, moderately, extremely, and severely stressed treatments. However, the differences in conductance and transpiration between slightly and moderately, moderately and severely, or severely and extremely stressed treatments were not significant $(p>0.05$, Fig. 1a, 1b). In severely and extremely stressed treatments, respectively, transpiration was $58 \%$ and $59 \%$, and conductance was $37 \%$ and $39 \%$ of those in wellwatered treatment. These declines were relatively small when compared to another major shrub species mesquite (Prosopis glandu-

\section{Table 1. Average soil water content $\left(\varphi_{\mathrm{p}}, \mathrm{cm}^{3} \mathrm{~cm}^{-3}\right)$, soil water potential (MPa) predicted by water retention curves developed from thermocou-

\begin{tabular}{|c|c|c|c|c|c|}
\hline & & & Treatm & & \\
\hline & $\mathbf{W W}^{\prime}$ & SS & MS & SVS & ES \\
\hline $\begin{array}{l}\text { Soil water } \\
\text { content } \\
\left(\mathrm{cm}^{3} \mathrm{~cm}^{-3}\right) \\
\text { SEM }(\mathrm{n}=5)\end{array}$ & $\begin{array}{l}0.221 \\
0.009\end{array}$ & $\begin{array}{l}0.124 \\
0.012\end{array}$ & $\begin{array}{l}0.080 \\
0.007\end{array}$ & $\begin{array}{l}0.067 \\
0.003\end{array}$ & $\begin{array}{l}0.056 \\
0.003\end{array}$ \\
\hline $\begin{array}{l}\text { Soil water } \\
\text { potential } \\
\text { (MPa) } \\
\text { SEM }(n=5)\end{array}$ & $\begin{array}{r}-0.023 \\
0.000\end{array}$ & $\begin{array}{r}-0.199 \\
0.007\end{array}$ & $\begin{array}{r}-1.10 \\
0.10\end{array}$ & $\begin{array}{r}-1.98 \\
0.09\end{array}$ & $\begin{array}{r}-3.40 \\
0.17\end{array}$ \\
\hline $\begin{array}{l}\text { Plant water } \\
\text { potential } \\
(\mathrm{MPa}) \\
\text { SEM }(n=3)\end{array}$ & $\begin{array}{r}-2.85 \\
0.25\end{array}$ & $\begin{array}{r}-3.48 \\
0.31\end{array}$ & $\begin{array}{r}-3.93 \\
0.50\end{array}$ & $\begin{array}{r}-5.94 \\
0.81\end{array}$ & $\begin{array}{r}-8.19 \\
1.20\end{array}$ \\
\hline $\begin{array}{l}\text { Plant RWC } \\
\text { SEM }(n=6)\end{array}$ & $\begin{array}{l}0.88 \\
0.02\end{array}$ & $\begin{array}{l}0.74 \\
0.02\end{array}$ & $\begin{array}{l}0.59 \\
0.02\end{array}$ & $\begin{array}{l}0.55 \\
0.04\end{array}$ & $\begin{array}{l}0.51 \\
0.01\end{array}$ \\
\hline
\end{tabular} ple psychrometry and midday water potential and relative water content (RWC) of broom snakeweed in June, 1991.}

'WW-well watered; SS-slightly stressed; MS-moderately stressed; SVS-severely stressed; ES-extremely stressed.

2Soil water coutent is the average of 5 sets of observations made once every month 2Soil water content is the average of 5 sets of observations made once every month
during April though August. Each set of observations produce 5 treatment means of $\phi_{\text {; }}$; each mean is based on 9 TDR readings on 3 pots of each treatment. 

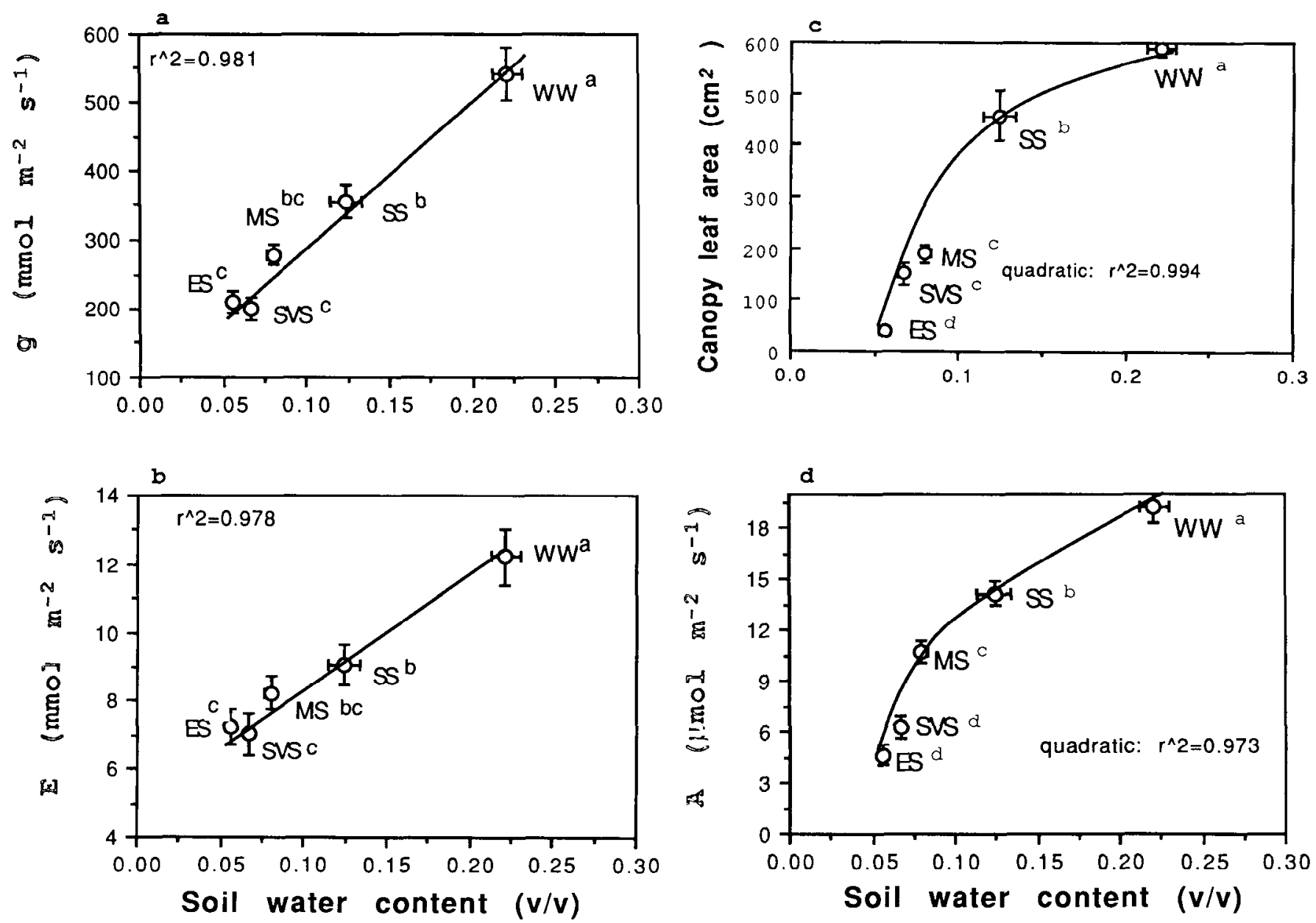

Fig. 1. a. Stomatal conductance, b. transpiration rate, c. canopy area development, and d. photosynthesis rate as influenced by soil water content in the well-watered (WW), slightly stressed (SS), moderately stressed (MS), severely stressed (SVS), and extremely stressed (ES) treatments. The vertical and horizontal bars represent \pm 1 standard error. Means followed by the same letter are not different at $p<0.05$.

losa Torr.) in which transpiration and conductance decreased 3.5and 6-fold, respectively, from a wet June to a drought in July (Wan and Sosebee 1991). DePuit and Caldwell (1975) suggested that when subjected to summer drought, diurnal stomatal control over water loss was less pronounced in broom snakeweed than in other semidesert species.

Canopy leaf area and photosynthesis responded curvilinearly to water stress (Fig. 1c, ld). Under slightly stressed treatment, leaf area and photosynthesis declined only $23-26 \%$. Then a break point was reached at which leaf area declined $68 \%$ in the moderately stressed treatment $(-1.1 \mathrm{MPa})$; photosynthesis declined $67 \%$ in the severely stressed treatment $(-2 \mathrm{MPa})$, indicating leaf area was more sensitive than photosynthesis to moderate soil water deficit.

Stomatal conductance was $34 \%$ less $(p<0.05)$ in the slightly stressed than in the well-watered treatment (Fig. 1a); the magnitude of the reduction in conductance was greater than the reduction in leaf area $(23 \%, p<0.05$, Fig. 1). There was significant reduction in leaf area $(p<0.05)$ but not in conductance $(p>0.05)$ in plants grown in the moderately stressed treatment as compared to those grown in the slightly stressed treatment. Canopy area in plants within the extremely stressed treatment decreased to only $25 \%$ of that in the severely stressed treatment $(p<0.05$, while conductance did not differ between extremely and severely stressed treatment. Under low soil water availability as in the extremely stressed treatment, canopy size became very low (Fig. 1c). Other studies have shown that for a given hydraulic conductivity of a stem, leaf specific conductivity increases with a decline in stem leaf area (Zimmerman 1983). This may explain why a slightly higher $\mathrm{g}$ was maintained in the cxtremely rather than in the severely stressed treatment.

According to Bradford and Hsiao (1982), canopy development is generally more sensitive to water stress than stomatal conductance for many species. Our data have shown somewhat different results; stomata of broom snakeweed seem to respond more sensitively to a mild water stress than canopy development does. As water stress increases, canopy development is more affected. These alternate modifications in leaf area and conductance in response to different levels of water stress suggest that leaf growth and stomatal conductance are attuned to regulate total water consumption in accordance with water supply.

Stomata were less responsive to water stress when soil water potential dropped to $<-1.1 \mathrm{MPa}$, i.e., in the moderately, severely, and extremely stressed treatments. In summer drought, water potential in the topsoil is often reduced to $<-1.5 \mathrm{MPa}$ (Wan and Sosebee 1991) and broom snakeweed usually sheds leaves during the summer (DePuit and Caldwell 1975). With a smaller canopy size, conductance often remains relatively high. Meinzer and Grantz (1990) found that sugarcane stomata adjusted to the ratio of total hydraulic conductance to total transpiring leaf area.

Leaf expansion in individual twigs produced distinct patterns of growth in the 5 treatments (Fig. 2). Plants in the well-watered treatment had the greatest leaf expansion rate followed by plants in the slightly stressed treatment. Plants in the extremely stressed treatment had a negative leaf growth. The mean leaf area in each 


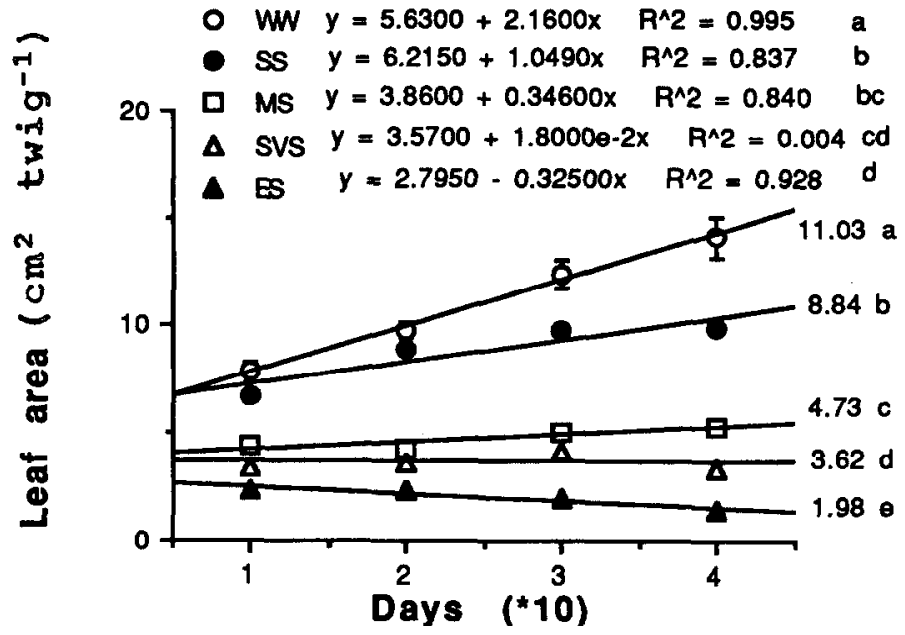

Fig. 2. Leaf area per twig during 21 May through 21 June. Slopes of the equations followed by the same letter are not different $(p<0.05)$. The numbers on the right of each line are the means of leaf area per twig, and they are different from each other $(p<0.05)$.

twig during May through June was also different $(P<0.05)$ between any 2 treatments. Slow leaf growth was observed in the moderately stressed treatment; leaf shedding was a prominent phenomenon in the severely and extremely stressed treatments. When soil water deficit reached $-1.1 \mathrm{MPa}$, leaf growth was severely inhibited. At soil water potential $<-2 \mathrm{MPa}$, the stress became sufficient that the plants shed leaves in order to keep balance with the soil water supply.

It is generally assumed that stomatal closure is a reversible response to drought. By using stomata to control water loss, plants can maintain higher productivity under a mild water stress $(-0.2$ $\mathrm{MPa}$ ) and avoid leaf senescence, which is an irreversible process and represents a loss of carbon. Leaf senescence occurs only when stress threatens plant survival (Bradford and Hsiao 1982).

Similarly, conductance was more reduced than photosynthesis $(26 \%)$ in plants grown in the slightly stressed treatment, while conductance was less affected than photosynthesis in plants in the moderately, severely and extremely stressed treatments (Fig. 1). Because of a greater degree of stomatal closure in plants grown in the slightly stressed treatment, broom snakeweed maintained intercellular $\mathrm{CO}_{2}$ concentration (259 $\mu \mathrm{L}^{-\mathrm{L}^{-1}}$, data not shown) comparable to that in the well-watered treatment $\left(263 \mu \mathrm{L} \mathrm{L}^{-1}\right)$, thus optimizing carbon gain with respect to water loss (Cowan 1982) and resulting in higher productivity. Intercellular $\mathrm{CO}_{2}$ concentration in snakeweed plants in severely and extremely stressed treatments became higher ( 283 and $290 \mu \mathrm{L} \mathrm{L}^{-1}$, respectively, $p<0.05$ ) than in those grown in the well-watered and slightly stressed treatments, reflecting a reduced photosynthetic capacity in the severely stressed plants (Farquhar and Sharkey 1982). Photosynthesis was more highly correlated with mesophyll conductance to $\mathrm{CO}_{2}\left(\mathrm{~g}_{\mathrm{m}}\right)$ $\left(r^{2}=0.955, p<0.0001, n=165\right.$, Fig. 3) than with stomatal conductance $\left(r^{2}=0.50, p<0.0001, \mathrm{n}=165\right)$. Mesophyll conductance includes diffusion of $\mathrm{CO}_{2}$ in the liquid pathway across cell wall, membranes, and the cytosol to carboxylation sites in the chloroplast, and carboxylation capacity and photochemistry in the chloroplasts (Bradford and Hsiao 1982). Mesophyll conductance can be affected by any changes in the above processes, some of which are related to mesophyll water status (Bradford and Hsiao 1982). The close correlation between photosynthesis and mesophyll conductance suggests the significance of nonstomatal control of photosynthesis in broom snakeweed and supports the research of Teskey et al. (1986) and Dang et al. (1991), who found that in woody plants

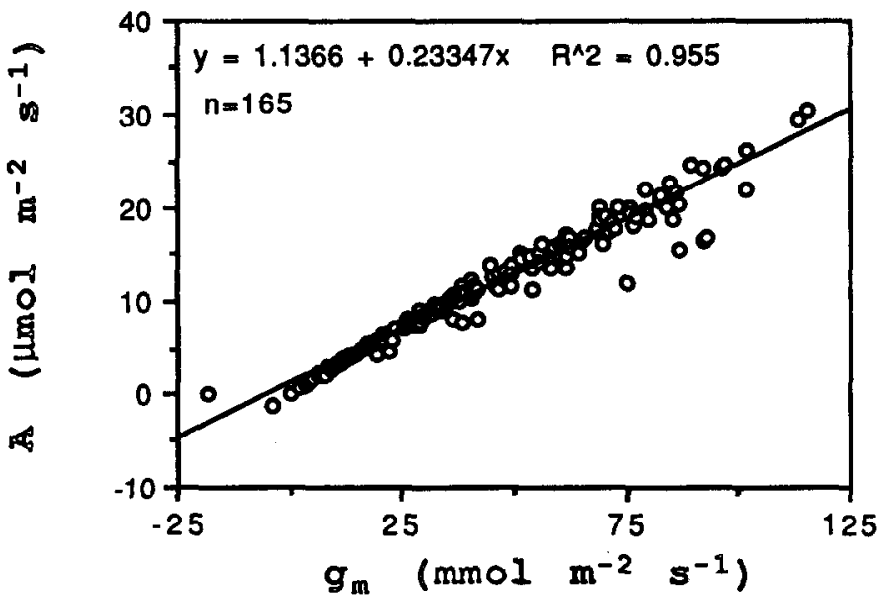

Fig. 3. Relationship between mesophyll conductance $\left(g_{m}, \mathrm{mmol} \mathrm{m}^{-2} \mathrm{~s}^{-1}\right)$ and photosynthesis $\left(A, \mu \mathrm{mol} \mathrm{m}^{-2} \mathrm{~s}^{-1}\right)$ and photosynthesis $(A, \mu \mathrm{mol} \mathrm{m}$ $\left.\mathrm{s}^{-1}\right)$. Each data point represents 1 observation.

photosynthesis is more limited by mesophyll conductance than by stomatal conductance. But, we have to interpret this with caution because an uncontrolled error may occur in the calculation of mesophyll conductance in which chloroplast $\mathrm{CO}_{2}$ concentration is usually assumed to be zero.

Water-use efficiency (WUE) at the single twig level remained the same for the well-watered and slightly stressed treatments, but declined dramatically in severely and extremely stressed treatments (Fig. 4). A moderate decline (17\% from the maximum value)

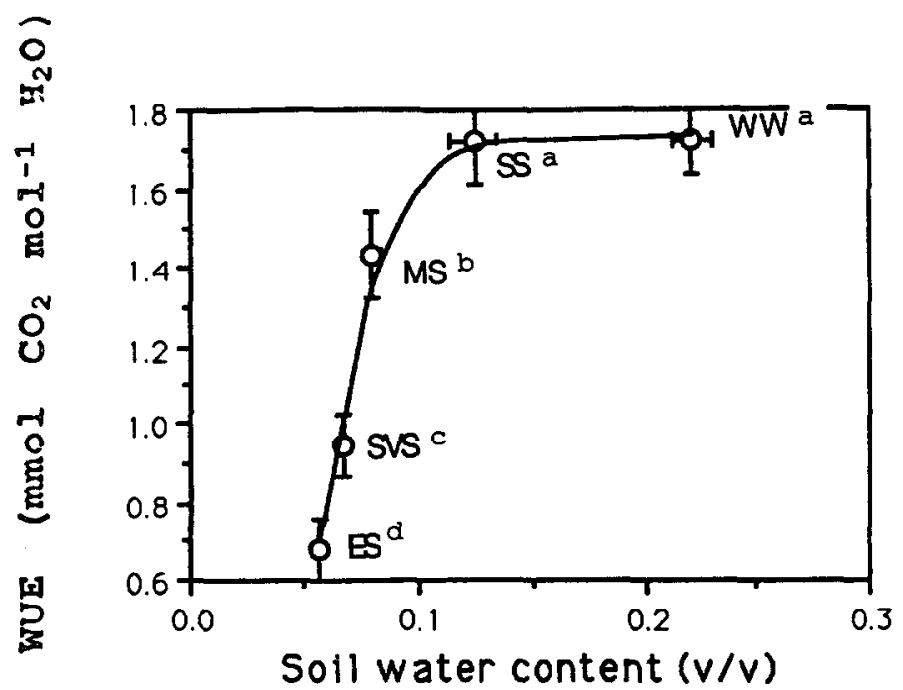

Fig. 4. Relationship between water-use efficiency (WUE, A/E mmol $\mathrm{CC}_{2} / \mathrm{mol}$ water) and soil water regime. The vertical and horizontal bars represent \pm 1 standard error.

occurred in moderately stressed treatment. Stanhill (1986) stated that water-use efficiency increased when plants were subjected to drought conditions because stomatal closure caused a proportionately greater reduction in transpiration than photosynthesis. DeLucia and Heckathorn (1989) found that water-use efficiency in both big sagebrush and ponderosa pine (Pinus ponderosa Laws) increased as soil drought increased. The opposite behavior exhibited by broom snakeweed is probably due to the predominance of nonstomatal limitation to photosynthesis and stomata less sensitive to severe water deficit. When photosynthetic capacity was greatly reduced under severe water stress, stomata remained par- 
tially open, which favored transpirational water loss over carbon fixation (Stanhill 1986).

The photosynthetic apparatus of broom snakeweed can tolerate extremely low soil water potential. The average total soil water potential in the extremely stressed treatment was $-3.4 \mathrm{MPa}$ but plant water potential was about $-8.1 \mathrm{MPa}$ (Table 1). However, broom snakeweed was able to maintain a positive average gas exchange at all sampling dates. This supports the field research of DePuit and Caldwell (1975), who found that when big sagebrush often had negative $\mathrm{CO}_{2}$ exchange rates in the droughty summer afternoons, photosynthesis in broom snakeweed remained positive. Since photosynthesis is significantly correlated with stomatal conductance $\left(r^{2}=0.50, p<0.0001, \mathrm{n}=165\right)$, we attribute the positive photosynthesis, to some extent, to the relatively higher stomatal conductance in the severely stressed plants.

Recovery of photosynthesis from water stress upon rewetting the soil is very fast in broom snakeweed. After all plants were irrigated at the end of the vegetative stage, photosynthesis in the extremely stressed treatment $\left(17.1 \mu \mathrm{mol} \mathrm{m}^{-2} \mathrm{~s}^{-1}\right.$, data not shown) approached that in the well-watered treatment $\left(19.2 \mu \mathrm{mol}^{-2} \mathrm{~s}^{-1}\right)$ within 2 days. This may be indicative of fast water uptake when soil is rewet.

Broom snakeweed has sensitive stomatal behavior under mild stress conditions (soil water potential $=-0.2 \mathrm{MPa}$ ). This is a tradeoff for maintaining a large canopy and hence a high productivity. However, native plant species are often exposed to a much drier soil environment (Caldwell 1985). Although most species close their stomata with increasing stress, stomata of broom snakeweed do not respond sensitively from moderate to extreme stress, which results in low water-use efficiency. Broom snakeweed has a shallow root system that gives it access to water at the same soil depth as most perennial grasses (Pieper and McDaniel 1989). A conservative strategy in water use (stomata sensitive to stress) might place this half-shrub at a disadvantage to its competitors whose root systems can take up water rather rapidly from the upper soil layers (Cohen 1970, Richards 1986). Therefore, an alternative strategy must be used in water consumption by broom snakeweed. In contrast, deep rooted species such as mesquite are largely free of competition for deep water reserves with the associated range species. The relatively conservative stomatal behavior observed in mesquite (Wan and Sosebee 1991) may help the plant to survive a prolonged drought. Because stomata of broom snakeweed remain partially open under water deficit, the plant tolerates a low internal water status as observed in this study.

In conclusion, stomatal conductance and transpiration in broom snakeweed were more sensitive to mild soil water deficit than photosynthesis and canopy development. In contrast, canopy development and photosynthesis were more sensitive to severe soil water deficit than stomatal conductance and transpiration, which results in low water-use efficiency. Broom snakeweed exhibits positive photosynthesis under very low internal water status. Therefore, we do not reject our hypothesis that the combination of low water-use efficiency and high degree of drought tolerance are the basic physiological traits in broom snakeweed that enable it to compete effectively for the limited water resource in the semiarid rangelands.

\section{Literature Cited}

Bradford, K.J., and T.C. Hsiao. 1982. Physiological responses to moderate water stress. p. 264-324. In: Lange O.L., P.S. Nobel, C.B. Osmond, and H. Ziegler (eds.), Physiological plant ecology. II. Springer-Verlag, Berlin, Heidelberg, N.Y.

Caldwell, M. 1985. Cold desert. p. 198-212. In: Chabot B.F., and H.A. Mooney (eds.), Physiological ecology of North American plant communities. Chapman and Hall, N.Y.

Cohen, D. 1970. The expected efficiency of water utilization in plants under different competition and selection regimes. Israel J. Bot. 19:50-54.

Comstock, J.P., T.A. Cooper, and J.R. Ehleringer. 1988. Seasonal patterns of canopy development and carbon gain in nineteen warm desert shrub species. Oecologia 75:327-335.

Cowan, I.R. 1982. Regulation of water use in relation to carbon gain in higher plants. p. 589-614. In: Lange, O.L., P.S. Nobel, C.B. Osmond, and H. Ziegler (eds.), Physiological plant ecology. II. Springer-Verlag, Berlin, Heidelberg, N.Y.

Dalton, F.N., and J.A. Poss. 1990. Soil water content and salinity assessment for irrigation scheduling using time-domain reflectometry: principles and applications. Acta Hortic. 278:381-393.

DeLucia, E.H., and S.A. Heckathorn. 1989. The effect of soil drought on water-use efficiency in a contrasting Great Basin desert and Sierran montane species. Plant Cell Environ. 12:935-940.

Dang, Q.L., V.J. Lieffers, R.L. Rothwell, and S.E. MacDonald. 1991. Diurnal variation and interrelations of ecophysiological parameters in three peatland woody species under different weather and soil moisture conditions. Oecologia 88:317-324.

DePuit, E.J., and M.M. Caldwell. 1975. Gas exchange of three cool semidesert species in relation to temperature and water stress. J. Ecol. 68:835-858.

Farquhar, G.D., and T.D. Sharkey. 1982. Stomatal conductance and photosynthesis. Annu. Rev. Plant Physiol. 33:317-345.

Fites, J.A., and R.O. Teskey 1988. $\mathrm{CO}_{2}$ and water vapor exchange in Pinus taeda in relation to stomatal behavior:test of an optimization hypothesis. Can. J. Forest. Res. 18:150-157.

Larcher, W. 1982. Physiological plant ecology, 2nd ed. Springer-Verlag, Berlin.

Ledieu, J., P. De Ridder, P. De Clerck, S. Dautrebande. 1986. A method of measuring soil moisture by time-domain reflectometry. J. Hydrol. 88:319-328.

Meinzer, F.C., and D.A. Grantz. 1990. Stomatal and hydraulic conductance in growing sugarcane:stomatal adjustment to water transport capacity. Plant Cell Environ. 13:383-388.

Pieper, R.D., and K.C. McDaniel. 1989. Ecology and management of broom snakeweed. p. 1-11. In: Proc.:Snakeweed:Problems and Perspectives. College of Agr. and Home Econ., New Mexico State Univ., Las Cruces.

Richards, J.H. 1986. Root form and depth distribution in several biomes. In: Carlisle D., W.L. Berry, I.R. Kaplan, and J.R. Watterson (eds.), Mineral exploration: Biological systems and organic matter. Rubey Vol. V. Prentice-Hall, Englewood Cliffs, N.J.

Sosebee, R.E. 1988. Life cycle of broom snakeweed. p. 7-10. In: Broom Snakeweed Conf. Proc., New Mexico Assoc. Conserv. Distr., Fort Sumner, N.M.

Stanhill, G. 1986. Water use efficiency. Adv. Agron. 39:53-85.

Teskey, R.O., J.A. Fites, L.J. Samuelson, and B.C. Bongarten. 1986. Stomatal and nonstomatal limitations to net photosynthesis in Pinus taeda L. under different environmental conditions. Tree Physiol. $2: 131-142$.

Topp, G.C., J.L. Davies, and A.P. Annan. 1980. Electromagnetic determination of soil water content: measurements in coaxial transmission lines. Water Resources Res. 16:574-582.

Topp, G.C., J.L. Davies, and A.P. Annan. 1982. Electromagnetic determination of soil water content using TDR: $I$. Applications to wetting fronts and steep gradients. Soil Sci. Soc. Amer. J. 46:672-678.

Wan, C., and R.E. Sosebee. 1991. Water relations and transpiration of honey mesquite on 2 sites in west Texas. J. Range Manage. 44:156-160.

Zimmerman, M.H. 1983. Xylem structure and the ascent of sap. SpringerVerlag, N.Y. 